\title{
Comparative Ecological Analysis of Five Freshwater Lakes in and Around Mumbai, India
}

\section{Mendonsa L and Vishnuprasad V*}

Botany Department, SIES College of Arts, Science and Commerce (Autonomous), Mumbai, India

*Corresponding author: V Vishnuprasad, Assistant Professor, Botany Department, SIES College of Arts, Science and Commerce (Autonomous), Sion, Mumbai, Maharashtra, India, Tel: 0091-8439429827; Email: vitu4life@rediffmail.com

\section{Review article \\ Volume 3 Issue 5}

Received Date: October 29, 2019

Published Date: November 26, 2019

DOI: $10.23880 /$ jenr- 16000178

\section{Abstract}

Quality of water is described by its Physical, Chemical and Biological Characteristics. Various anthropogenic activities like disposal of sewage and industrial water, recreational activities, excess fertilization of lands and use of pesticides have polluted the water bodies. Water quality index is one of the most effective tools to communicate information on the quality of water to the concerned citizens and policymakers. Since lakes form a small yet complex and fragile ecosystem, they readily accumulate all types of pollutants. In a metropolitan city like Mumbai, such freshwater lakes are mostly surrounded by residential areas or industries due to which they constantly face disposal of all types of waste. At the same time, the lakes form a constant source of drinking water for many residents. Five lakes in and around the metropolis were selected in this study and ecological analysis revealed the dangerous threshold values of pollutants in them, which requires timely intervention for the safety and health of the inhabitants who are dependent upon them. The lakes were selected on the basis of their location, the use, amount of apparent pollution and the aesthetics. The ecological health of these lakes has been comparatively studied and analyzed for nine ecological and eco-physiological parameters giving interesting findings.

Keywords: Anthropogenic Activities; Water Quality Index; Freshwater Lakes; Ecological health

Abbreviations: APHA: American Public Health Association; ASTM: American Society of Testing and Material; BIS: Bureau of Indian Standards; BOD: Biochemical Oxygen; COD: Chemical Oxygen Demand; DO: Dissolved Oxygen; EBT: Eriochrome Black; TEC: Electric Conductivity; EDTA: Ethylenediaminetetraacetic Acid; GIS: Geographic Information System; PH: Potential Of Hydrogen; TDS: Total Dissolved Solids; TSS: Total
Suspended Solid; WHO: World Health Organisation; WQI: Water Quality Index.

\section{Introduction}

Water being one of the most essential abiotic components of the ecosystem, quality of water is described by its physical, chemical and biological 


\section{Journal of Ecology \& Natural Resources}

characteristics. Various anthropogenic activities like disposal of sewage and industrial water, recreational activities, excess fertilization of lands and use of pesticides have polluted the water bodies. Water quality index is one of the most effective tools to communicate information on the quality of water to the concerned citizens and policymakers [1].

Lakes are the dynamic inland aquatic ecosystem that supports and maintain a balanced adaptive community of organism having a large species biodiversity and the functional organization of all the organism support unique biotic integrity. Lakes, a significant aquatic ecosystem which has life-supporting systems are facing ecological degradation now a day because of undesirable anthropogenic activities. The health of the lake and their biological diversity are directly related to the health of almost every component of the ecosystem. Lakes are also subjected to various natural processes taking place in the environment like the hydrologic cycle, with unprecedented development activities; human beings are responsible for choking several lakes to death. Lakes have a complex and fragile ecosystem, as they do not have selfcleaning ability and therefore readily accumulate pollutants.

The metropolitan city of Mumbai is blessed with many lakes which form a very valuable natural resource. The inhabitants around the lakes are dependent on the lakes for various purposes like fishing, drinking, etc. resulting in excess water pollution continuously. Some industries use different chemicals \& the effluents are disposed of in these lakes. The literature survey reveals that very little investigation reports are available on the quality of above mentioned in and around Mumbai. In the absence of any research work on lake environments in and around Mumbai, it is hard to arrive at conclusion scientifically about their current status.

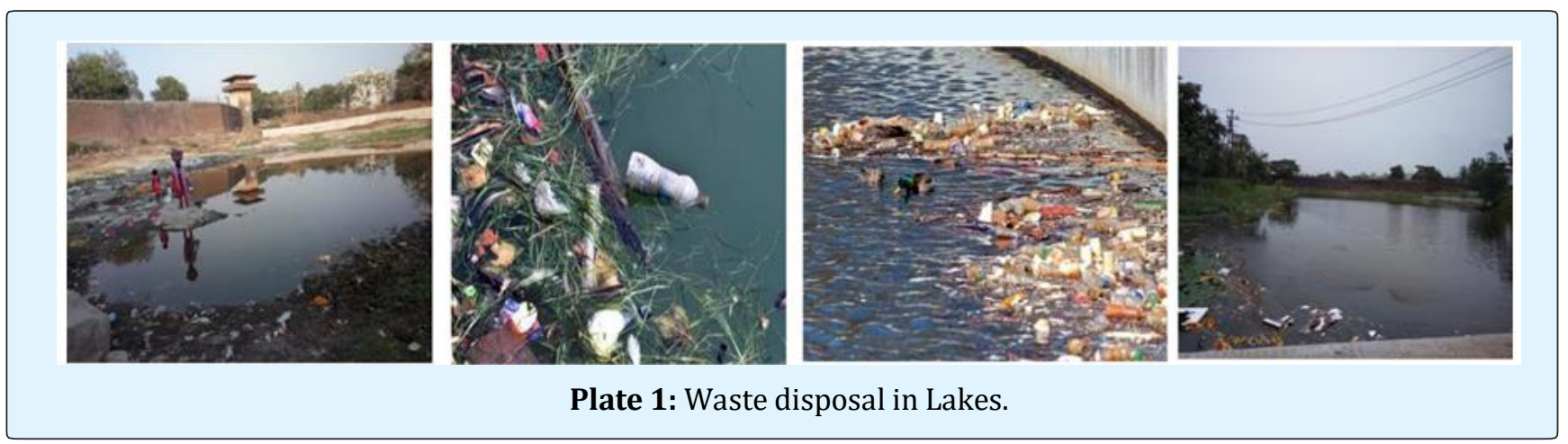

\section{Review of Literature}

The quality of water is described by its physical, chemical and microbial characteristics. The study helps us to understand that the fluctuations in the water quality have a significant influence on the basic communities. Therefore, an extensive review was carried out to throw light on the research work done in this field. Arivoli Appavu, et al. [2] studied the water quality parameters of Cauvery river water in Erode region. They revealed that how the water is contaminated by effluents from small scale industries and dumping of wastages from markets and domestic use wastages. So water quality management is urgently required to achieve the water quality standards. According to the studies done by Nagamani, et al. [3] on the physicochemical analysis of water samples, it showed that the hardness of the water in the urban areas is more as compared to rural areas and all parameters were within the permissible limits. Ramya, et al. [4] studied the hardness in groundwater samples by EDTA titrimetric method. They revealed there is falls nation that hard water is harmful to health, it's not hard water, it's very hard water $(<188 \mathrm{ppm})$. The minerals that are supplemented to the body through water will be beneficial to health in several ways. So, the public should be educated about degrees of hardness and its effects. According to the studies done by Devendra Dohre, et al. [1] on the analysis of groundwater quality suggested that evaluation of the water quality parameter as well as its management should be carried out periodically for water resource preservation. Gosomji \& Okooboh [5] in his studies determined the concentration of dissolved oxygen in water samples from Pankshin town to monitor water pollution. Sirajudeen, et al. [6] carried out the work on groundwater for evaluating the water quality index of the water samples collected from Ampikapuram area near Tiruchirappalli district. Gorde \& Jadhav [7] studied the quality of water and their physiochemical parameters 
such as temperature, $\mathrm{pH}$, electrical conductivity, hardness, alkalinity, acidity, BOD, COD and DO. Jena, et al. [8] performed a physiochemical assessment of groundwater from different sites in Bhilai, Chhattisgarh. Singare, et al. [9] carried out studies in Water Pollution at Bhavan's College Lake in Andheri where it was observed that annual average values of $\mathrm{pH}$, alkalinity, Biological oxygen demand (B.O.D), Chemical oxygen demand (C.O.D), Dissolved oxygen (D.O) and total hardness were higher than the tolerable limits set by Central Pollution Control Board (CPCB). Singare [10] studied the impact assessment of pollution in some lake water in and around Thane City where it was observed that the physicochemical parameters and level of toxic heavy metal content were found to be very much above the permissible limits, thereby making lake water harmful to the aquatic life and unsuitable for drinking or irrigation purpose. Manjare, et al. [11] performed a study on the periodical assessment of the physicochemical parameters of Tamadalge water tank in Kolhapur district, Maharashtra. Premlata Vikal [12], worked on the physicochemical characteristics of the Pichola lake water. Winder Ryan [13] studied the $\mathrm{pH}$, salinity, clarity of water samples from various locations around the world. Water quality content varies from community to community and from throughout the world a number of variances are natural differences caused by nature, and some are induced by a human. Koliyar \& Rokade [14] studied the dissolved oxygen, chemical oxygen demand, salinity, total hardness, conductivity and alkalinity in Powai lake where it was observed that these parameters were found to be increased during the summer season and have got diluted during the rainy season. Aftab Begum [15] studied various physicochemical parameters to analyze untreated fertilizer effluent. Dey [16] analyzed various physiochemical parameters of three different river samples and it was observed that dilution during rainy season decreases the metal concentration level to a considerable extent. Chavan [17] studied the different organic pollutants present in the Thane creek water. The creek water showed high values of BOD and COD along with 15 phenolic compounds, detergents, alcohols, ether and acetone which are harmful to aquatic life. The origin of these pollutants is mainly from the entry of effluents from the surrounding industries. Dwivedi BK and GC Pandey [18] studied the physicochemical factors and algal diversity of two water bodies in Faizabad. Mustapha MK [19] presented the flora and fauna communities of Oyun lake in Kwara state. Strzepek, et al. [20] analyzed the new methods of modeling water availability for agriculture under climate change. Kirkwood [21] reported that safe drinking water for human consumption should be free from pathogens such as bacteria, viruses and protozoan's parasites; meet the standard guidelines for taste, odour, appearance and chemical concentrations and in adequate quantities for domestic purposes.

\section{Materials and Methods}

The present study was carried out for a period of 7 months from September 2018 to March 2019.

\section{Study Areas}

The lakes selected for the present study are located in and around Mumbai. Following lakes were selected for sample collection and subsequent analysis.

i. Karnala Lake - Karnala Lake is located in Panvel in Karnala Bird Sanctuary, which is in the outskirts of Mumbai city, nestled inside a lush green forest. This lake was selected keeping in mind the least amount of pollution, thereby serving as a control sample for all the parameters. The coordinates are between Latitude $18^{\circ} 53^{\prime} 33^{\prime \prime} \mathrm{N}$ and Longitude $73^{\circ} 6^{\prime} 48^{\prime \prime} \mathrm{E}$.

ii. Kala Talao - Kala Talao is a historic lake in Kalyan, built by Adil Shah of Bijapur and located about a kilometer to the north of Kalyan Railway station. It is maintained by KDMC and is utilized by the public for various leisure and cultural activities including rituals etc. Several NGO's are monitoring and spreading general awareness regarding conservation and management of existing water bodies. The coordinates are between Latitude $19^{\circ} 14^{\prime} 40^{\prime \prime} \mathrm{N}$ and Longitude $73^{\circ} 07^{\prime} 51^{\prime \prime} \mathrm{E}$ and covers around 24 acres with varying depths ranging from 6-14 feet.

iii.Adharwadi Lake - The Lake next to the Jail and central maiden area is known as the Jail Lake by many, but the lake was initially called Castle Tank. It located about a kilometer to the north of Kalyan Railway station. This lake apparently had the maximum amount of pollution. There was an overgrowth of too many algae. Washing of clothes, dumping of religious debris, etc was rampant in this lake. The coordinates are between Latitude $19^{\circ} 15^{\prime} 20^{\prime \prime} \mathrm{N}$ and Longitude $73^{\circ} 7^{\prime} 39^{\prime \prime} \mathrm{E}$ and cover around 10,938 sq.feet.

iv.Jagannath Kasinath Salvi Talao - Shivaji Talao is located at Kalva near the railway station. It is surrounded on all sides by slums, the inhabitants of which are dependent upon the water of this lake for drinking, cooking, fishing, etc. Dead fish were found to be floating in some parts of the lake. The coordinates are between Latitude $19^{\circ} 11^{\prime} 33^{\prime \prime} \mathrm{N}$ and Longitude $72^{\circ} 59^{\prime} 42^{\prime \prime} \mathrm{E}$ and cover around 24,266 sq.feet.

v. Shivaji Talao - Shivaji Talao is located in Bhandup. It is a small lake surrounded by garden for recreational 


\section{Journal of Ecology \& Natural Resources}

purposes. Regular cleaning activities were found to be taking place in this lake. The coordinates are between

Latitude $19^{\circ} 50^{\prime} 50^{\prime \prime} \mathrm{N}$ and Longitude $75^{\circ} 55^{\prime} 46^{\prime \prime} \mathrm{E}$.

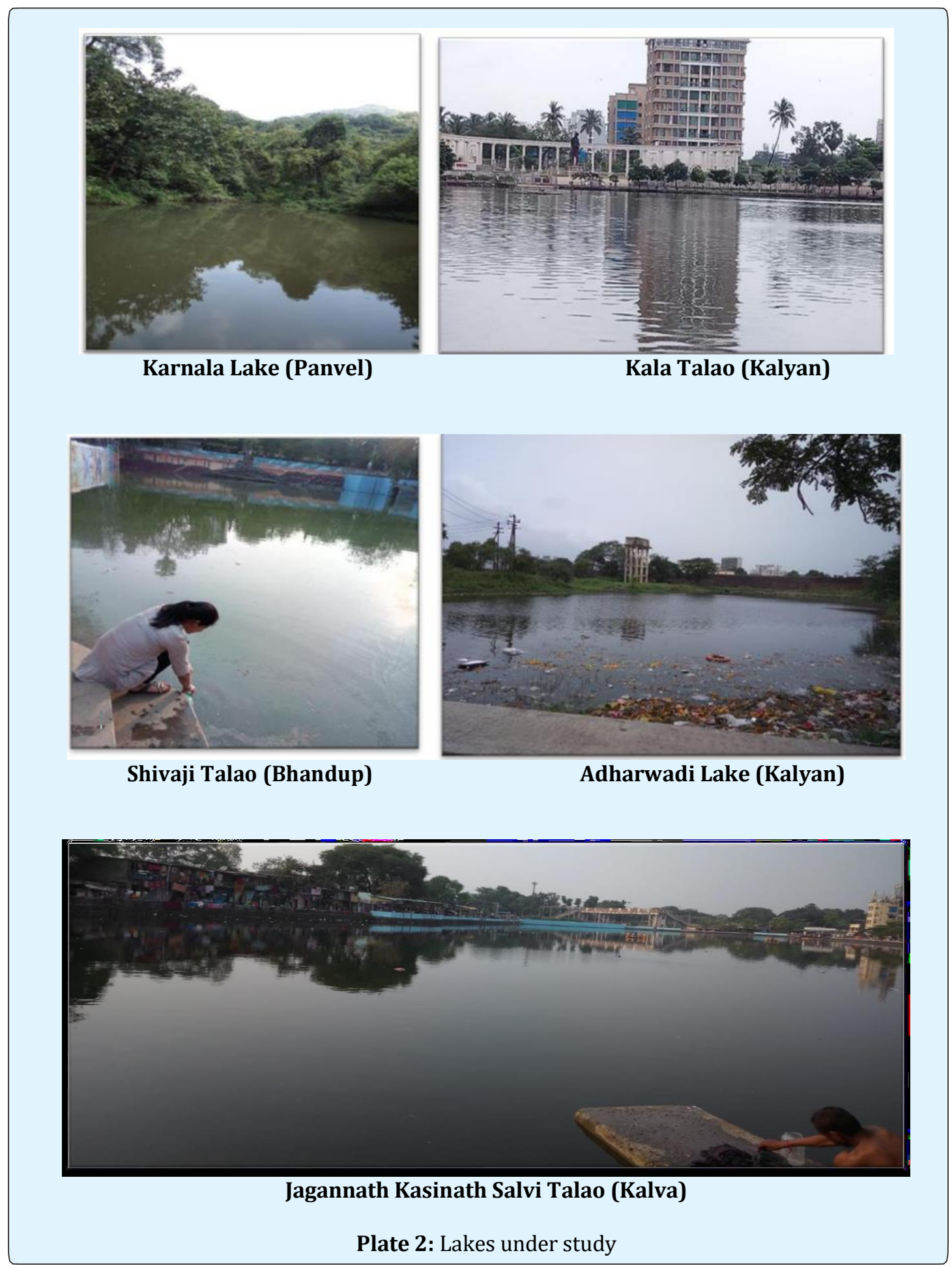

Mendonsa L and Vishnuprasad V. Comparative Ecological Analysis of 


\section{Journal of Ecology \& Natural Resources}

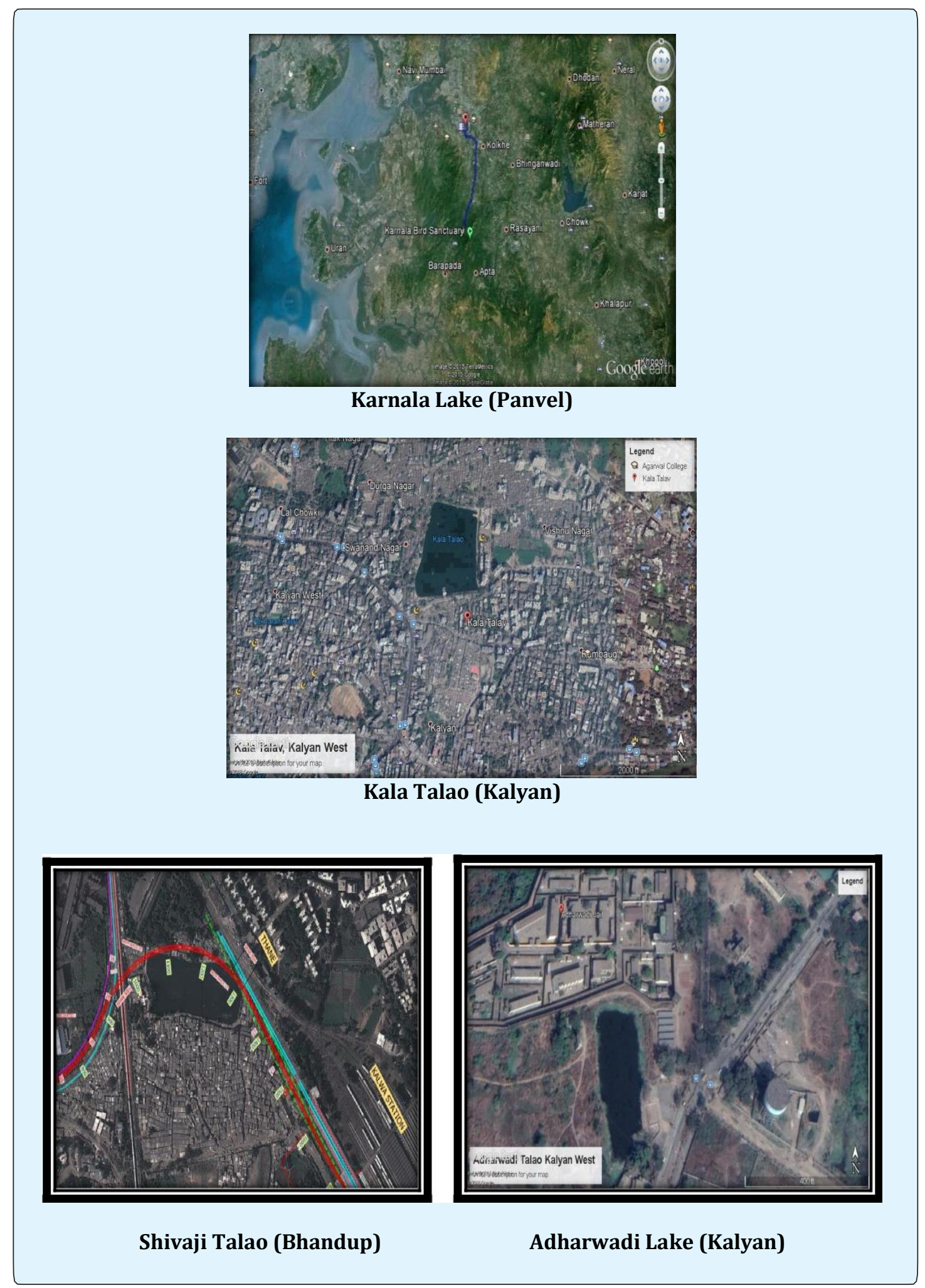




\section{Journal of Ecology \& Natural Resources}

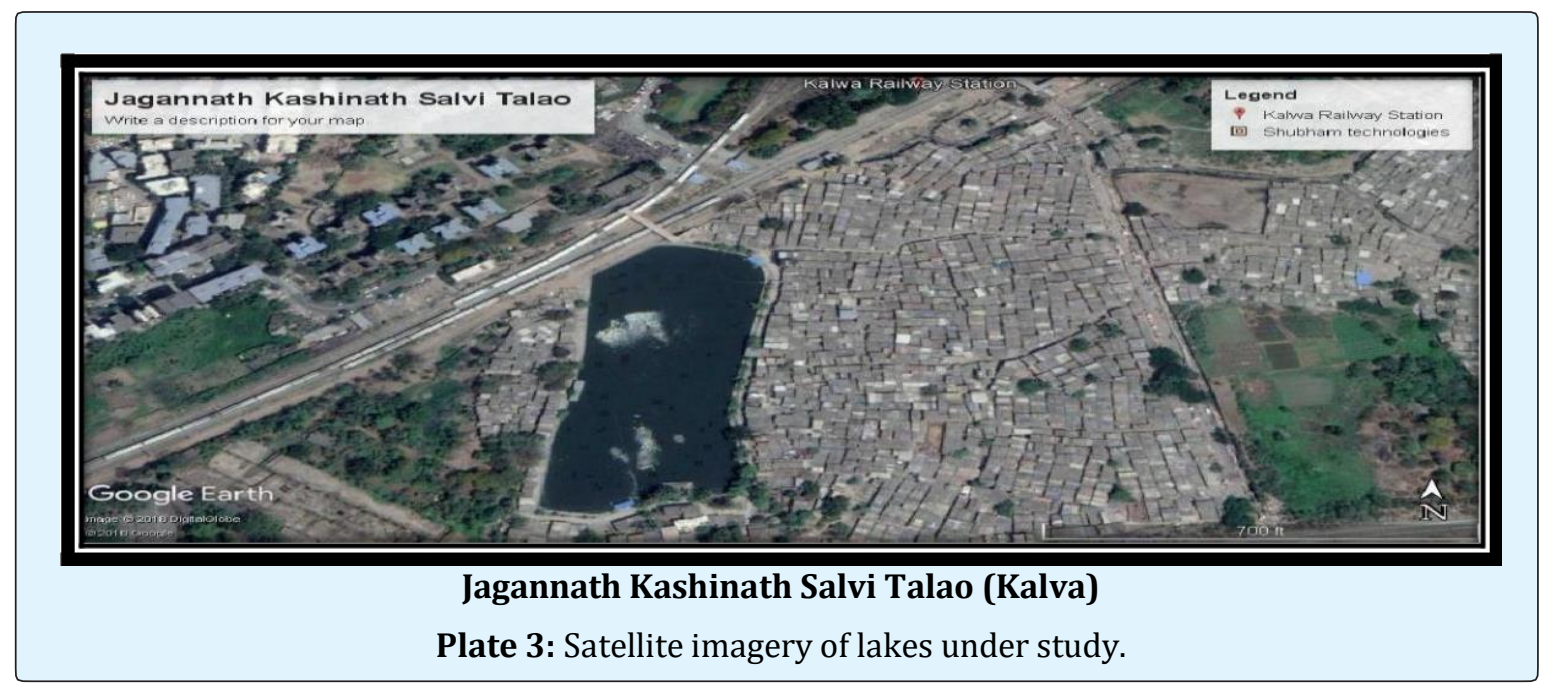

\section{Collection of Water Samples}

The water samples were collected separately from five lakes and collection was done at three sites around the three-corner named accordingly as sample one, two and three. Water samples were collected in new well rinsed and pre-cleaned plastic bottles, properly labelled and covered with black paper. The temperature of water was recorded at the site with the help of a mercury thermometer. After collection, water samples were brought to the research laboratory. Samples were analysed based on standard procedures of water analysis.

\section{Physicochemical Analysis}

The lake water samples collected were taken to the laboratory covered with black paper and were analysed with respect to different physicochemical parameters like $\mathrm{pH}$, Temperature, Hardness, Alkalinity, Acidity, Electrical conductivity, Biological Oxygen Demand (BOD) Chemical Oxygen Demand (COD) and Dissolved oxygen in order to get an idea of the WQI.

\section{pH}

The $\mathrm{pH}$ value of water is important in water treatment and industrial processes Velautham M [22]. The IS: 15000 give the limiting range of $\mathrm{pH}$ for drinking water to be 6.5 to 8.6. The $\mathrm{pH}$ of the lake water samples under study was assessed as per the method given by Winder Ryan [13] using Systronics $\mathrm{pH}$ meter at room temperature.

\section{Temperature}

In polluted water, temperature causes profound effect on DO and BOD levels thereby hampering aquatic ecology.
The perfect temperature range for lake water samples should be $20^{\circ}$ to $24^{\circ}$ Celsius. The temperature of the lake water samples was checked using thermometer in laboratory and also at the site for accuracy and better results.

\section{Electrical Conductivity}

The electrical conductivity of the lake water samples was checked as per the method given by Arivoli Appavu [2] using Systronics conductivity meter.

\section{Total Hardness}

The hardness of the lake water samples was assessed as per the method given by Winder Ryan [13]. According to this method, each lake water sample was taken in to a conical flask and was buffered to $\mathrm{pH}$ 10.1. An indicator dye like Eriochrome Black T (EBT) was added. The solution turned wine red due to reaction between indicator dye and the calcium and magnesium ions present in the water sample. The water sample was titrated against Ethylene diamine tetra acetic acid (EDTA) which complexes with magnesium and calcium icons and removes them from association with the indicator dye. When all the magnesium and calcium ions were consumed by EDTA, the dye turned blue and indicated the end point of titration.

\section{Alkalinity}

Alkalinity in natural water bodies is mainly due to salts of weak acids. The Alkalinity of the lake water samples was assessed as per the method given by Winder Ryan [13]. It was determined by phenolphthalein as 
indicator and by titrating it with sulphuric acid of known values of $\mathrm{pH}$, volume and concentration.

\section{Acidity}

In natural fresh waters, the acidity is mainly due to presence of free $\mathrm{CO} 2$ in the form of carbonic acids. The acidity of the lake water samples was measured as per the method given by Dohare [1]. The method measures the hydrogen ions present in the water sample as a result of dissociation or hydrolysis of solutes due to its reaction with standard alkali $(\mathrm{NaOH})$.

\section{Dissolved Oxygen}

The Dissolved oxygen of the lake water samples was measured using the method given by Gosamji and Okooboh [5]. According to this method, $50 \mathrm{ml}$ of lake water sample was taken in a $150 \mathrm{ml}$ beaker. To the beaker, $2 \mathrm{ml}$ of $\mathrm{MnSO}_{4}$ solution, $1 \mathrm{ml}$ of $\mathrm{KI}$ solution, $1 \mathrm{ml}$ of $\mathrm{KOH}$ solution and 4 drops of concentrated sulphuric acid were added. Once all the reagents were mixed thoroughly, $20 \mathrm{ml}$ of the prepared water sample was taken into a conical flask and starch solution was added as indicator until the water sample turned blue colour. The water sample was titrated with the $\mathrm{Na}_{2} \mathrm{~S}_{2} \mathrm{O} 3$ solution till blue colour disappears.

\section{Biological Oxygen Demand}

BOD is a measure of organic pollutant load. The Biological oxygen demand (BOD) of the lake water samples was assessed as per the method given by Paul
Keddy [23]. For determination of BOD, the water sample was collected separately into two BOD bottles. The dissolved oxygen of one BOD bottle was measured immediately (zero hour incubation) and the other BOD bottle was kept in light for 5 days after which the dissolved oxygen was measured.

\section{Chemical Oxygen Demand}

The COD of water sample is a measure of the oxidizable organic matters present in the water sample. COD of the lake water sample was assessed as per the method given by Champika [24]. $10 \mathrm{ml}$ of $\mathrm{KMnO}_{4}$ solution $(0.0125 \mathrm{M})$ was added into a stopper bottle containing $100 \mathrm{ml}$ of lake water. Then $10 \mathrm{ml}$ of $\mathrm{H}_{2} \mathrm{SO}_{4}(2.5 \mathrm{M})$ was added to it. Control flask was prepared in similar manner by adding the said reagents in $100 \mathrm{ml}$ of distilled water. Both the flasks were placed in boiling water bath for 30 minutes. Then the flasks were removed and allowed to cool at room temperature. $3 \mathrm{ml}$ of KI solution (0.3M) was added to each flask and shaken well. $10 \mathrm{ml}$ of the resultant solution was pipetted out and titrated against $\mathrm{Na}_{2} \mathrm{~S}_{2} \mathrm{O}_{3}$ $(0.0125 \mathrm{M})$ solution until a faint yellow colour is obtained. A few drops of starch indicator were added to obtain blue colour and the titration was continued until the solution turned colourless.

\section{Observations and Results}

The results obtained after all the analysis has been represented graphically as follows.

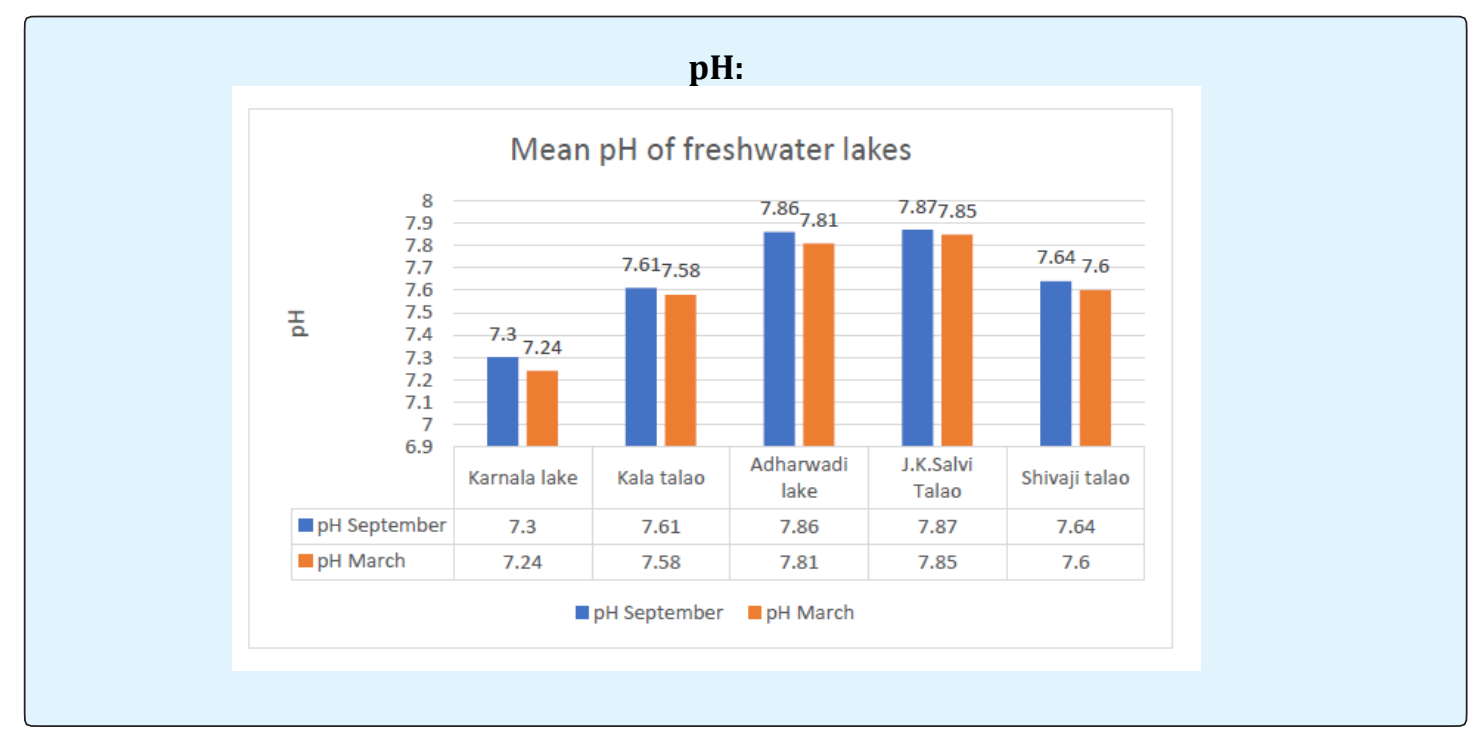

Mendonsa L and Vishnuprasad V. Comparative Ecological Analysis of Five Freshwater Lakes in and Around Mumbai, India. J Ecol \& Nat Copyright(C) Mendonsa L and Vishnuprasad V. Resour 2019, 3(5): 000178. 
Journal of Ecology \& Natural Resources
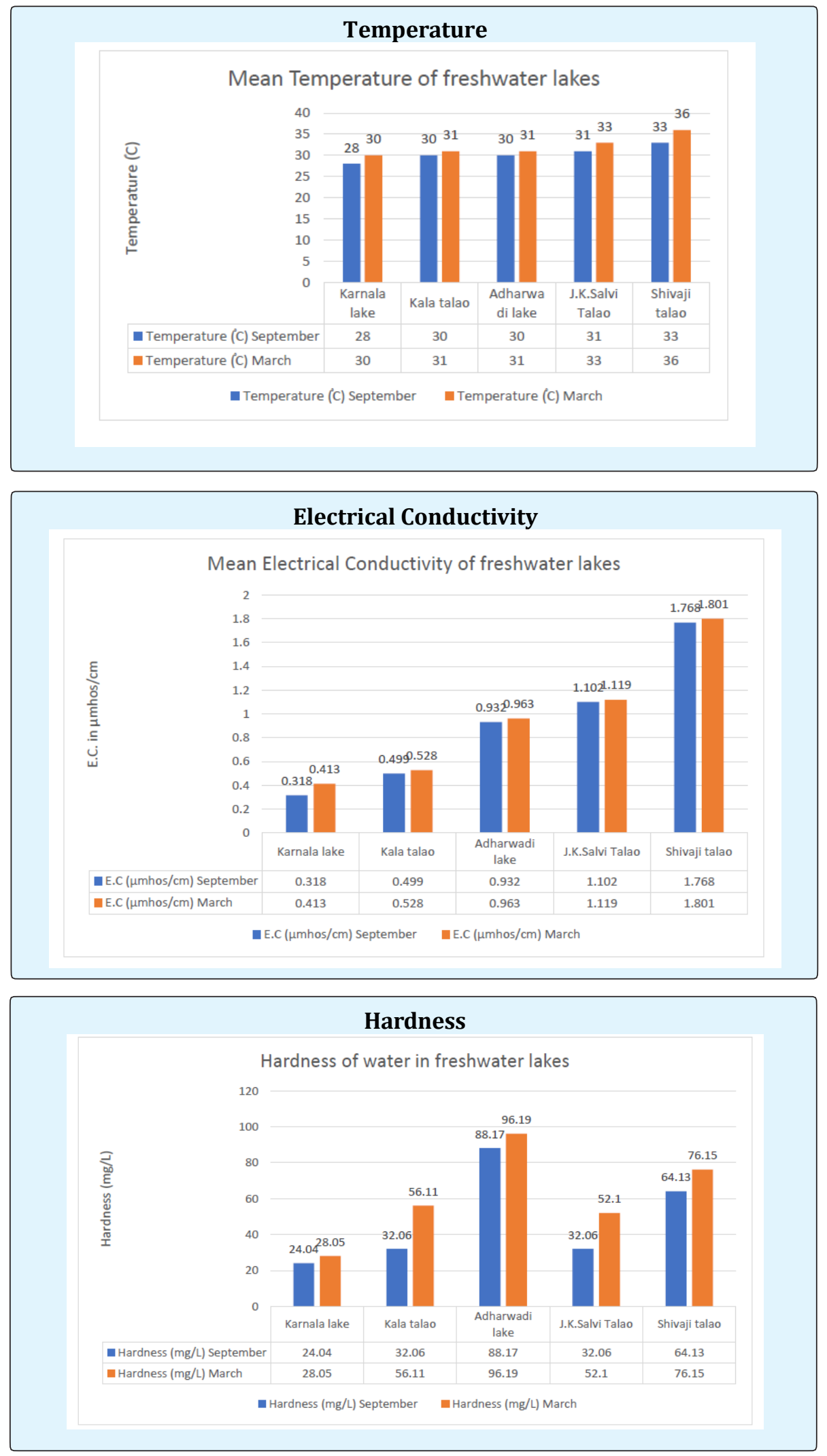

Mendonsa L and Vishnuprasad V. Comparative Ecological Analysis of Copyright@ Mendonsa L and Vishnuprasad V.

Five Freshwater Lakes in and Around Mumbai, India. J Ecol \& Nat Resour 2019, 3(5): 000178. 

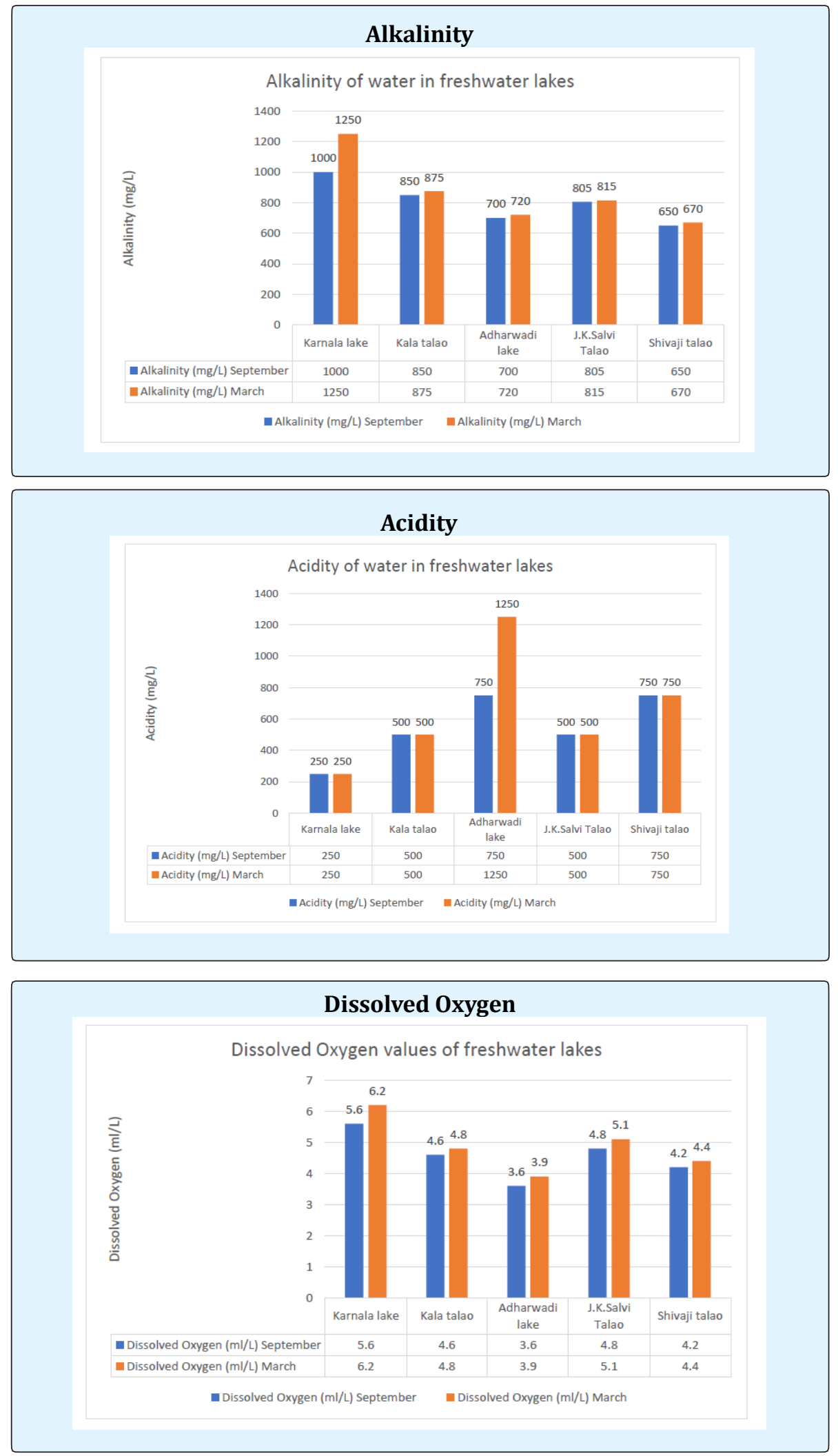

Mendonsa L and Vishnuprasad V. Comparative Ecological Analysis of Copyright(C Mendonsa L and Vishnuprasad V.

Five Freshwater Lakes in and Around Mumbai, India. J Ecol \& Nat Resour 2019, 3(5): 000178. 

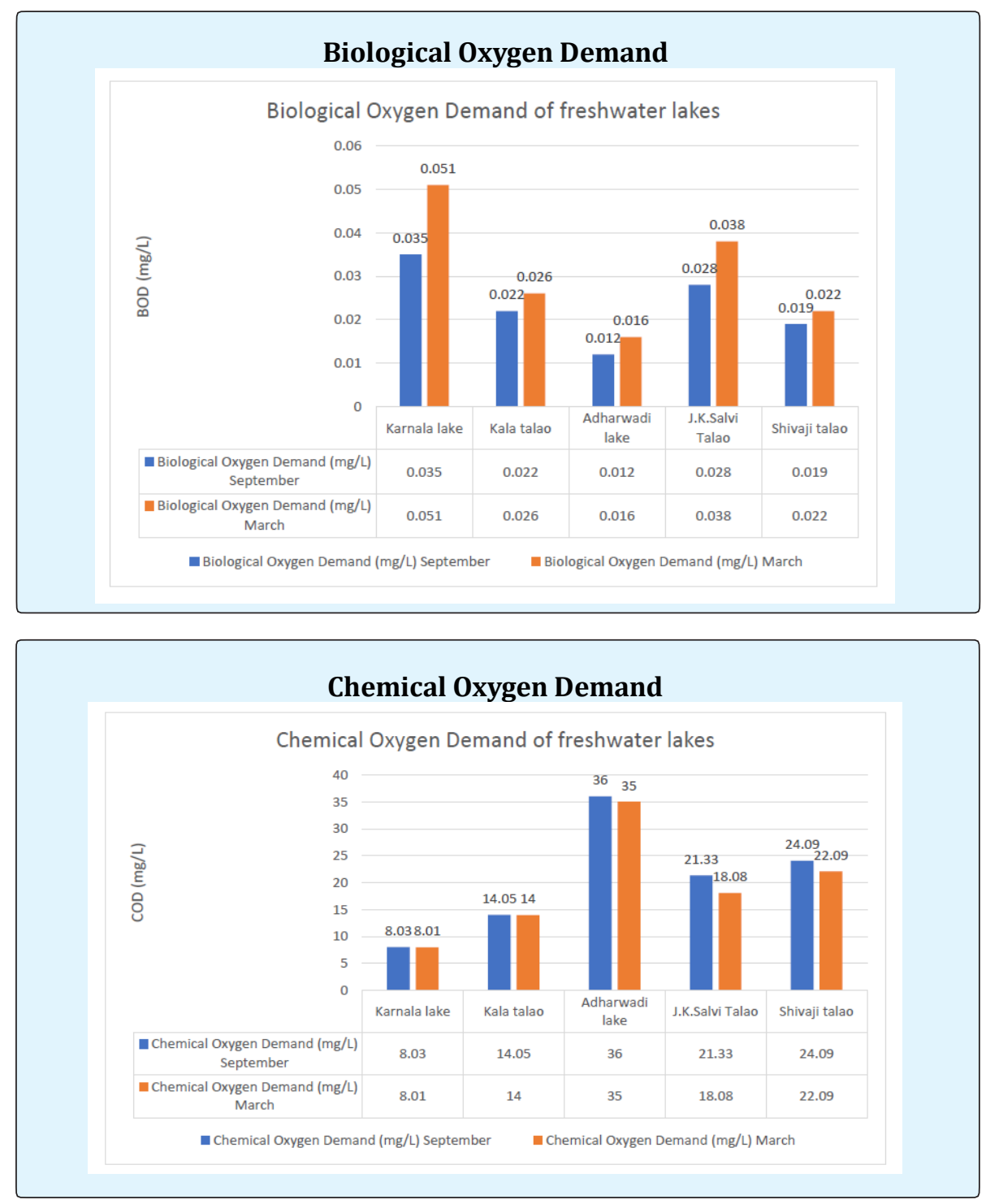

\section{Discussion}

Water does contain different types of floating, dissolved, suspended and microbiological impurities. The introduction of pollutants into an aquatic ecosystem can set off a complicated series of biological and chemical reactions. Therefore, it is very essential and important to test the water before it is used for domestic, agricultural or for industrial purposes.

Physico-chemical study is very essential to get the exact idea about the quality of water. Various aspects of physico-chemical characteristics and impacts of pollution in lake water quality have been reported by a number of workers in India and abroad. However, there is a paucity of data regarding the physico-chemical characteristics of lakes in and around Mumbai. Therefore, to fill up the gap of knowledge, lake water quality of five different lakes in and around Mumbai was assessed in the present study.

A considerable number of agencies dealing with public health and environmental protection, viz. BIS, ICMR, USEPA, WHO, CPCB have provided standard values of different physico-chemical and ecological parameters tagging the cleanliness or pollution of aquatic ecosystems. These standards have been found useful in determining water quality and health. In the present study, these 
standards are used as reference values for comparison and discussion.

\section{pH}

The $\mathrm{pH}$ is a measure of the intensity of acidity or alkalinity and measures the concentration of hydrogen ions in water. It has no direct adverse effect on health; however, a low value below 4.0 will produce sour taste and higher value above 8.5 shows alkaline taste. $\mathrm{A} \mathrm{pH}$ range of $6.5-8.5$ is normally acceptable as per the guidelines suggested by ISI. In the present study, $\mathrm{pH}$ ranged from neutral to slightly alkaline. Highest $\mathrm{pH}$ was found in Jagannath Kasinath Salvi talao (7.87 in September and 7.85 in March) while lowest in Karnala lake (7.30 in September and 7.24 in March). Mondal [25] reported positive relation between quality of lake water and $\mathrm{pH}$ of water and sediments. The present results are in accordance with those of Banerjee [26] who reported neutral to slightly alkaline $\mathrm{pH}$ ranges to be most favorable to aquatic life. This $\mathrm{pH}$ range is considered to be congenial for aquatic production owing to greater availability of most of the nutrient elements and also due to increased biological activities under this $\mathrm{pH}$ range [27].

\section{Temperature}

Temperature affects the physical and chemical properties of water and also has an impact on the aquatic vegetation, organisms and their biological interactions. Rise in temperature speeds up the chemical reactions and reduces the solubility of gases in water. The temperature of water in the study area varied from $28^{\circ} \mathrm{C}$ to $36^{\circ} \mathrm{C}$. The minimum temperature was observed in Karnala Lake and the maximum was observed in Shivaji Talao. This temperature range is found out to be higher than that reported by Choudary \& Singh [28], who studied on water samples from Sasaram and reported the temperature range to be between $23^{\circ} \mathrm{C}$ to $27^{\circ} \mathrm{C}$. This variation in the temperature of lake water may be attributed to the geographical location, climate pattern and season of collection of water samples.

\section{Electrical Conductivity}

Electrical conductivity (EC) is a numerical expression of ability of an aqueous solution to conduct an electric current. The highest EC was recorded at Shivaji Talao (1.801 $\mu \mathrm{mhos} / \mathrm{cm}$ in the month of March and $1.768 \mu \mathrm{mhos} / \mathrm{cm}$ in the month of September) while that of lowest EC was found out at Karnala lake $(0.413 \mu \mathrm{mhos} / \mathrm{cm}$ in March and $0.318 \mu \mathrm{mhos} / \mathrm{cm}$ in September). These results are in accordance with those of Boyd CE [27] who found out that the natural water usually have EC values between the range of $0.318-1.801 \mu \mathrm{mhos} / \mathrm{cm}$. From values all the sample sites reported values in the permissible WHO [29] recommended guideline value of 0.05- $200 \mu \mathrm{mhos} / \mathrm{cm}$. The difference in EC value may be attributed to several factors like the presence of different ions, their concentration, mobility, temperature of measurement and so on. Sastry KV [30] found out that the concentration of dissolved solids is proportional to the ionic strength of the water sample and further proposed that the increase in conductivity is may be due to the infiltration of leachate from soil.

\section{Total Hardness}

Hardness of water is a measure of its capacity to form precipitates with soap. It scales with certain anions present in the water. Hardness values were lowest at Karnala lake $(28.05 \mathrm{mg} / \mathrm{L}$ in March and $24.04 \mathrm{mg} / \mathrm{L}$ in September) and highest at Adharwadi Talao $(96.1 \mathrm{mg} / \mathrm{L}$ the month of March and $88.17 \mathrm{mg} / \mathrm{L}$ in the month of September). According to APHA [31], the desirable limit for total hardness is $300 \mathrm{mg} / \mathrm{L}$, As compared to the standard APHA limit, the hardness of the lakes under study was found out to lie within the desirable range. Mishra [32] studied the pond water quality in Rairangpur, Varanasi and found that the hardness value varies from 146 to $268 \mathrm{mg} / \mathrm{L}$.

\section{Alkalinity}

Alkalinity of water is a measure of its capacity to neutralize strong acids. Total alkalinity is the sum of hydroxides, carbonates and bicarbonates present in water. Presence of bicarbonate was the major cause for the alkalinity of all the lakes under study. In the present study, Phenolphthalein Alkalinity was absent in all samples and Methyl Orange Alkalinity ranged from $131 \mathrm{mg} / \mathrm{L}$ to $230 \mathrm{mg} / \mathrm{L}$. it was found of that the alkalinity of every lake under study was found to within the permissible WHO standard limits. The Karnala lake reported the highest alkalinity with maximum concentration of bicarbonates $(230 \mathrm{ppm})$ whereas the Shivaji Talao had minimum concentration of bicarbonates (142 ppm) and hence the lowest alkalinity. The variation in the concentration of bicarbonates may be attributed to the activity of aquatic organisms which uptake or release carbon dioxide and thereby change the proportion of carbonates and bicarbonates present in the water [27].

\section{Acidity}

Acidity of natural water is derived principally from the salts of strong acids. Acidity is an important parameter in determining the quality of water which ultimately 
determines the biotic composition of the systems [33]. The minimum acidity values were recorded at Karnala Lake $(250 \mathrm{mg} / \mathrm{L})$ and the maximum acidity value was reported in Adharwadi Talao $(1250 \mathrm{mg} / \mathrm{L})$.

\section{Dissolved Oxygen (DO)}

The correlation of DO with water body gives direct and indirect information about the bacterial activity, photosynthesis, availability of nutrients, stratification etc. [12]. The dissolved oxygen of the lakes understudy ranged between $3.6 \mathrm{mg} / \mathrm{L}$ at Adharwadi Lake and $6.2 \mathrm{mg} / \mathrm{L}$ at Karnala Lake. The dissolved oxygen in water may decrease due to also due to increased microbial activity $[34,35]$.

\section{Biological Oxygen Demand (BOD)}

BOD is the amount of dissolved oxygen required for the biochemical decomposition of organic compounds and the oxidation of certain inorganic materials (e.g., iron, sulfites). Hence, estimation of biochemical oxygen is a key test in water pollution and waste treatment process control. The permissible value recommended for BOD is 5 $\mathrm{mg} / \mathrm{L}$ as per Indian standards. In the present investigation, the BOD of the lakes fluctuated between $0.012 \mathrm{mg} / \mathrm{L}$ and $0.051 \mathrm{mg} / \mathrm{L}$. Karnala Lake indicated more amount of BOD as compared to other lakes. The amount of BOD was found to be least in Adharwadi Lake.

\section{Chemical Oxygen Demand (COD)}

Like BOD it is also an index of organic enrichment of pond water. The standard limit set by WHO [36] is 10 ppm. In the present study, the chemical oxygen demand was found to be minimum at Karnala Lake $(8.01 \mathrm{mg} / \mathrm{L})$ and maximum at Shivaji Talao (24.09 mg/L). Shinde [37] reported the COD of Harsool-Savangi Dam, Aurangabad to be $2.7 \mathrm{ppm}$. Chaurasia and Pandey [38] studied the physicochemical parameters of lakes in AyodhyaFaizabad and reported COD to be as high as 52.3ppm. Chattopadhyay [39] found out the optimum COD value for aquatic life to be between 80 and 100 ppm.

\section{Conclusion}

The present investigation was focused on measuring the physico-chemical parameters of five different lakes in and around Mumbai to throw light on the lake water health and aquatic life. In all total nine parameters, viz. $\mathrm{pH}$, temperature, hardness, alkalinity, acidity, electrical conductivity, dissolved oxygen, biological oxygen demand and chemical oxygen demand were examined. The intensive investigation of the lakes revealed the following conclusions.

1) Presently, some of the lake selected in and around for present study are environmentally suitable for the existence of living organisms.

2) However, it was also noticed that most of the lakes are liberally utilized as dumping grounds for residential, religious waste and agricultural wastes. This may lead to water pollution and serious health problems in future for the village community.

3) The physico-chemical parameters understudy varied greatly for different lakes.

4) Most of these parameters were within the acceptable limit except electrical conductivity, DO, BOD and COD. This indicates the signs of varied degrees of water pollution.

5) Out of five lakes studied, three lakes viz. Karnala Lake, Kala Talao and Jagannath Kasinath Salvi Talao recorded the lowest values for $\mathrm{pH}$, Hardness, Acidity and COD and thus, reported to be good not only for aquatic life but also for human consumption and use.

6) Presently, Jagannath Kasinath Salvi Talao was not showing any high signs of water pollution after the installation of water purifier in the centre of the lake.

7) Amongst the lakes studied, Adharwadi Lake was found to be the most polluted lake as it recorded highest values for $\mathrm{pH}$, temperature, electrical conductivity, hardness, acidity and COD. It may be due to excessive use of the lake by the inhabitants for various activities like washing, bathing, cleaning, release of religious waste, dumping of wastes, etc.

Thus, the present study forms a platform for the future remedial work for the lake water health maintenance in and around Mumbai.

\section{Conflicts of Interest}

The authors declare that there is no conflict of interest between them.

\section{Acknowledgement}

The authors express their sincere gratitude to the Principal Dr. Uma Shankar and all the staff of the Botany Department of SIES College of Arts, Science and Commerce (Autonomous), Sion, Mumbai for providing the platform and the necessary infrastructure for carrying out this research project without any hindrance. 


\section{Journal of Ecology \& Natural Resources}

\section{References}

1. Devendra D, Deshpande S, Kotiya A (2014) Analysis of ground water quality parameters: A review. Res J Eng Sci 3(5): 26-31.

2. Appavu A, Thangavelu S, Muthukannan S, Jesudoss JS, Pandi B (2016) Study of water quality parameters of Cauvery river water in Erode region. J Global Biosci 5(9): 45564567.

3. Nagamani C, Saraswathidevi C, Shalini A (2015) Physico-chemical analysis of water samples. Int J Scienti Eng Res 6(1): 902-968.

4. Ramya P, Jagadeesh AB, Tirupati Reddy B, Venkateshwara LR (2015) A study on the estimation of hardness in ground water samples by EDTA titrimetric method. Int J Recent Scienti Res 6(6): 4505- 4507.

5. Gosomii AD, Okooboh MA (2013) Determination of the concentration of dissolved oxygen in water samples from Pankshin town to monitor water pollution. Chem Materials Res 3(3): 286-312.

6. Sirajudeen J, Manikandan A, Manivel V (2013) Water Quality Index of Ground Water around Ampikapuram area near Uyyakondan canal Tiruchirappalli Tamil Nadu. Arch Appl Sci Res 5(3): 21-26.

7. Gorde SP, Jadhav MV (2013) Assessment of water Quality parameters: A Review. J Eng Res Appl 3(6): 2029-2035.

8. Jena V, Dixit S, Gupta S (2012) Physico-Chemical Parameters assessment of ground water in different sides of Bhilai city, Chhattisgarh, Rasayan. J Chem 5(4): 168-201.

9. Singare PU, Trivedi M, Mishra RM (2012) Sediment Heavy Metal Contaminants in Vasai Creek of Mumbai: Pollution Impacts. Ame J Chem 2(3): 171-180.

10. Singare PU (2011) Distribution Behaviour of Trace and Toxic Metals in Soil and Sediment along the Thane Creek near Mumbai, India. Interdisciplinary Environmental Review 12(4): 298-312.

11. Manjare SA, Vhanalakar SA, Muley DV (2010) Analysis of water Quality using Physico-Chemical parameters Tamdalge Tank in Kolhapur District, Maharashtra, Int J Adv Biotechnol Res 1(2): 115-119.
12. Premlata V (2009) Multivariant analysis of drinking water quality parameters of Lake Pichhola in Udaipur, India. Biological Forum- An International Journal 1(2): 86-91.

13. Winder Ryan, Serenity Pender, Bernard Lynch (2008) A study of pH, Salinity, and Clarity of water samples from various locations around the world, Elizabeth city, North Carolina 4: 21-86.

14. Koliyar JK, Rokade NS (2008) Water Quality in Powai Lake, Mumbai. The $12^{\text {th }}$ Lake Conference.

15. Aftab-begum SY, Noorjahan CM, Dawood S (2005) Physico-chemical and fungal analysis of a fertilizer factory effluent. Nat Environ \& Pollut Technol 4(4): 529-531.

16. Dey K, Mohapatra SC, Misra B (2005) Assessment of water quality parameters of the river Brahmani at Rourkela. J Industrial Pollution Control 21(2): 299304.

17. Chavan RP, Lokhande RS, Rajput SL (2005) Monitoring of organic pollutants in Thane creek water. Nature Environ Pollut Technol 4(4): 633-636.

18. Dwivedi BK, Pandey GC (2002) Physico-chemical factors and algal diversity of two ponds in Faizabad. India. Pollution Research 21(3): 361-370.

19. Mustapha MK (2002) A pre-impoundment survey of the flora and fauna communities of Oyun lake in Ilorin, Kwara state, Nigeria. Nigerian J Pure Appl Sci 17: 1200-1209.

20. Strzepek K, Rosenzweig C, Major D, Iglesias A, Yates D, et al. (1999) New methods of modeling water availability for agriculture under climate change. Water Resource Association 35(6): 1639-1655.

21. Kirkwood (1998) Water Annual Water Quality Report M 06010430.

22. Velayutham MK (2001) Some quality parameters of ground well water in the Jaffna peninsula. Department of Chemistry, University of Jaffna, Sri Lanka, B. Sc. Thesis pp 85.

23. Keddy PA (2010) Wetland Ecology: Principles and Conservation. Cambridge University Press. ISBN 0521739675. 
24. Champika SP (1993) Water quality and treatment, University of Peradeniya, Sri Lanka.

25. Mondal NK, Datta JK, Banerjee A (2011) Pond alkalinity: A study in Burdwan municipality, Burdwan, West Bengal, India. Int J Environ Sci 1(7): 1718-1724.

26. Banerjee SM (1967) Water quality and soil conditions of fish ponds in some states of India in relation to fish production. Ind J Fisheries 14(1-2): 115- 144.

27. Boyd CE (1978) Water Quality in Warm Water Fish Ponds, Agricultural Experiment station, Auburn University 359-378.

28. Choudary SN Singh, Sunita Singh (2014) Physicochemical and biological parameters of the three ponds of Sasaram of Bihar. Int J Appl Sci Biotechnol 2(2): 206-210.

29. WHO guidelines for drinking water quality, $2^{\text {nd }}$ (Edn.), Recommendations, World Health Organization Geneva 1: 30-113.

30. Sastry KV, Rathee P, Sukla V (1999) Ground Water Characteristics of Rohtak and Bahadurgarh. Environ Ecol 17: 105-108.

31. APHA (1985) Standard Methods for Examination of Water and Wastewater. American Public Health Association, Washington DC.

32. Mishra S, Singh AL, Tiwary D (2014) Studies of Physico-chemical Status of the Ponds Varanasi Holy
City under Anthropogenic Influences. Int J Environ Res Develop 4(3): 261-268.

33. Sahni K, Yadav S (2012) Seasonal variations in physico-chemical parameters of Bharawas Pond, Rewari, Haryana. Asian J Experi Sci 26(1): 61-64.

34. Moss B (1972) Studies on Gull Lake, Michigan II. Eutrophication: evidence and prognosis. Fresh Water Biol 2(4): 309-320.

35. Morrissette DG, Mavinic DS (1978) BOD Test Variables. J Environ Eng Division 6: 1213-1222.

36. WHO Geneva (2008) Guidelines for drinking-water quality (electronic resource), $3^{\text {rd }}(E d n$.), Incorporating $1^{\text {st }}$ and $2^{\text {nd }}$ agenda, Volume 1 , Recommendations.

37. Shinde SE, Pathan TS, Raut KS, Sonawane DL (2011) Studies on physico chemical parameters and correlation coefficient of Harsool-Savangi Dam, Aurangabad, India. Middle-East J Sci Res 8(3): 544554.

38. Chaurasia M, Pandey GC (2007) Study of PhysicoChemical Characteristics of Some Water Ponds of Ayodhya Faizabad. Indian J Environ Protect 27(11): 1019-1023.

39. Chattopadhyay GN (1998) Chemical Analysis of Fish Pond Soil and Water. Daya Publishing House, New Delhi, pp: 13-66. 